\title{
Critical Analysis of Sedation and Analgesia in Severe Head Trauma
}

\section{Análise crítica da sedação e analgesia no traumatismo craniano grave}

\author{
${ }^{1}$ Department of Neurosurgery, Santa Casa Hospital; Ribeirão Preto, \\ São Paulo, Brazil \\ 2 Faculdade Atenas, Paracatu, Minas Gerais, Brazil \\ ${ }^{3}$ Department of Pathology, Universidade de São Paulo, \\ Neurointensivism, Hospital Sírio Libanês, São Paulo, SP, Brazil \\ ${ }^{4}$ Department of Neurosurgery, Universidade de São Paulo, Neuro- \\ oncology and Neurointensivism, Hospital Sírio Libanês, São Paulo, \\ SP, Brazil \\ ${ }^{5}$ Department of Neurosurgery, Santa Casa Hospital, Ribeirão Preto, \\ São Paulo, Brazil \\ ${ }^{6}$ Department of Neurosurgery of FBHC and Neurosurgery Service, \\ Aracaju, Sergipe, Brazil
}

Nícollas Nunes Rabelo ${ }^{1}$ Neiffer Nunes Rabelo ${ }^{2}$ Fabio Santana Machado ${ }^{3}$

Marcos Augusto Stávale Joaquim ${ }^{4}$ Luiz Antônio Araujo Dias Junior ${ }^{5}$ Carlos Umberto Pereira ${ }^{6}$

Address for correspondence Nícollas Nunes Rabelo, MD, Av. Antonio Diederichsen, n190, Ap 193, Jardim América, CEP: 14020250, Ribeirão Preto, SP, Brasil (e-mail: nicollasrabelo@hotmail.com).

Arq Bras Neurocir 2016;35:135-147.

\begin{abstract}
Introduction Head injury is a direct determinant of morbidity, disability, and mortality in the young population. Sedatives and analgesics are commonly used in patients with brain injury to retrieve an ICP, CMRO2, and CBF, preserving the cerebral regulation system and self-avoiding hypotension.

Objective The objective of this paper is to review on this topic, linking the main drugs, side effects, costs, anxiolytic properties, anticonvulsants, and correlating them with complacency and brain metabolism.

Methods We perform a literature review using PubMed database, MEDLINE, EMBASE, Science Direct, The Cochrane Database, Google Scholar, and Clinical trials. We selected papers from the period between 1958 and 2014, which totaled 254 papers. Of these, we selected 129 papers based on keywords, inclusion, and exclusion criteria.

Evidence Review The volume of the brain decreases due to dislocation of the CBV out

Keywords

- brain injury

- intracranial hypertension

- sedation

- analgesia of the skull. The main sedatives and analgesics are propofol, midazolam, etomidate, ketamine, barbiturates, dexedetomedina, morphine, fentanyl, alfentanil, sulfenatil, and remifentanil. We hereby discuss the algorithm for a fast intubation sequence and the algorithm for intracranial hypertension treatment regarding the systematic sedation therapy. A range of sedatives and analgesic agents are available for sedation. Each class has its own positive and negative effects on neurotrauma patients.
\end{abstract}

received

November 14, 2015

accepted

January 26, 2016

published online

April 15, 2016
DOI http://dx.doi.org/

10.1055/s-0036-1582447. ISSN 0103-5355.
Copyright $\odot 2016$ by Thieme Publicações License terms

Ltda, Rio de Janeiro, Brazil
(요 (1) $\Theta \circledast$ 


\section{Resumo}

\author{
Palavras-chave \\ - lesão cerebral \\ - hipertensão \\ intracraniana \\ - sedação \\ - analgesia
}

Conclusions The correct analysis of sedation and analgesia in neurotrauma, rapid sequence intubation, and management of medications in intracranial hypertension can lead to an ideal management of brain injury.

Introdução Traumatismo Craniano (TCE) é determinante direto na morbidade, incapacidade e mortalidade na população jovem. Sedativos e analgésicos são comumente usados em pacientes com lesão cerebral com o objetivo de recuperar PIC, CMRO2 e FBC, preservando o sistema de autorregulação cerebral, evitando hipotensão. Objetivo O objetivo deste trabalho é fazer uma revisão sobre este tema, correlacionando as principais drogas, efeitos colaterais, custos, propriedades ansiolíticas, anticonvulsivantes, correlacionando com complacência e metabolismo cerebral.

Métodos Revisão da literatura utilizando base de dados PubMed, MEDLINE, EMBASE, Science Direct, The Cochrane Detabase, Google Scholar, ensaios clínicos. Os trabalhos selecionados de 1958 a 2014. Somou-se 254 trabalhos. Foram selecionados 129, através de palavras-chave, inclusão e critérios de exclusão.

Evidência Revisão O volume do cérebro é reduzido devido o deslocamento do volume cerebral. Os principais sedativos e analgésicos são: propofol, midazolam, etomidato, cetamina, barbitúricos, a dexmedetomidina, morfina, fentanil, alfentanil, sulfato, remifentanil. Discute-se algoritmo para a sequência rápida de intubação e algoritmo para tratamento de hipertensão intracraniana. Uma série de sedativos e analgésicos agentes estão disponíveis para sedação. Cada classe tem seu próprio efeitos positivos e negativos em pacientes no neurotrauma.

Conclusões e Relevância O presente trabalho contribui com a análise correta da sedação e analgesia em neurotrauma, sequência rápida de intubação e administração de medicamentos para analgesia e sedação em hipertensão intracraniana, e um ideal manejo na lesão cerebral.

\section{Introduction}

Trauma is a leading cause of death in people between 1 and 44 years. Traumatic brain injury (TBI) is the main determinant of morbidity, disability, and mortality within this age group. Severe TBI is associated with a 30 to $70 \%$ mortality rate, and the recovery of survivors is marked by severe neurological sequels and a severely impaired quality of life. TBI means any aggression traumatic order that results in anatomic injury or functional impairment of the scalp, skull, meninges, the brain or its vessels. ${ }^{1,2}$

Brain injuries and their coverage occur in $\sim 200$ out of 100,000 people per year and account for 14 to 30 deaths among 100,000 people per year in the United States. The most common cause of TBI is through vehicles, followed by falls from heights (pediatric and geriatric predominates in this group), and by firearms. The incidence in men is two to three times higher than in women and the most common age range is from 15 to 24 years, with a secondary peak after 65 years. The seriousness of the problem is complicated by behavioral sequelae, even in relatively small head injuries. ${ }^{3,4}$

Sedatives and analgesics are agents commonly used in critically ill patients. The use of sedatives in neurotrauma patients in both the operating room and the intensive care unit is extremely important to know what effects these drugs or drug combinations have on brain metabolism and intracranial compliance. Cerebral vasodilation may result in increased intracranial pressure (ICP) or oxygen consumption $\left(\mathrm{CMRO}_{2}\right)$. In addition, these agents can affect the cerebral perfusion pressure (CPP), as many have potent effects on mean arterial pressure (MAP). Other concerns involving the use of these agents include time until wake-up after the interruption and the effects on patient outcome. Cost is also becoming an increasingly important factor to consider in the choice of drug therapy. ${ }^{5}$

Severe trauma patients present with risk of hypotension and cerebral vasodilation due to brain injury. Hypotension reduces cerebral perfusion pressure, cardiac output, and peripheral resistance. Self-regulation persists only in the blood pressure range of $60-150 \mathrm{mmHg}$. Different values start to trigger the mechanisms of brain swelling and impaired cerebral metabolic physiology, like increases of cerebral vasodilation (CVS), cerebral swelling, $\mathrm{CMRO}_{2}$ and ICP. ${ }^{6}$

Objective of this study is to perform a literature review on the main effects of analgesia and sedation in severe TBI, relate the main drugs and their effects, correlating with metabolism and brain compliance. We also propose algorithms for rapid sequence intubation in TBI and intracranial hypertension to systematize the sedation therapy. 


\section{Materials and Methods}

We conducted a literature review using as a database PubMed, MEDLINE, EMBASE, Science Direct, the Cochran Database, Google Scholar, and Clinical Trials. We selected works from the period of 1958 to 2014. There were a total of 254 works, from which 129 were selected according to exclusion criteria. We also performed a manual search in medical journals and magazines regarding the brain metabolism in severe TBI. Articles with incomplete clinical data were not included in the work. We also deleted those focused on TBI approach, surgical types, and behaviors of cerebral injury. The main topics determined are presented below.

\section{Sedation and Analgesia}

Knowledge of brain metabolism is very important to understand the braińs self-protection mechanisms in the face of acute brain injury. The brain volume decreases simply because of the partial displacement of the cerebral blood volume (CBV) outside the skull with head elevation (single measure for drainage of venous blood), control mean arterial pressure (MAP), cerebral perfusion pressure (CPP), cerebrospinal fluid drainage, stimulation of vasoconstriction inducers brain (hypercapnia), and decreased chest compressions. The mechanisms are centered in: maintenance of cerebral autoregulation, reduced cerebral consumption (cerebral metabolic rate for oxygen - $\mathrm{CMRO}_{2}$ ), and cerebral blood flow $(\mathrm{CBF}) .^{7-20}$

Agents that lead to cerebral vasoconstriction are benzodiazepines, etomidate, propofol, lidocaine, and barbiturates (from smallest to greatest effect). They can behave differently depending on the applied dosage. The following medications have the effect of (a) reducing cerebrospinal liquor: fentanyl, halothane isoflurane, pentobarbital, nitrous oxide; (b) increasing cerebrospinal liquor: enflurane and ketamine; (c) reducing the ICP: thiopental, etomidate, lidocaine, benzodiazepine, droperidol, and narcotics; and (d) increase ICP: halothanes, enflurane, succinylcholine, and isoflurane. - Table 1 shows the relationship of analgesia and sedation drugs with their pharmacological characteristics. ${ }^{21-30}$

Sedation has a significant effect on energy expenditure. In postoperative patients, an increase in the depth of sedation progressively decreased metabolism. There is a reduction in VO2 after the application of adequate diet in sedated patients. $^{31}$ The goal of controlled hypothermia with sedation and neuromuscular blockade (NMB) in patients with TBI is to reduce intracranial hypertension, avoiding coughing and agitation into the fan, and to eliminate tremors. ${ }^{32-35}$

Malnutrition has been associated with increased morbidity and mortality and prolonged length of stay. Providing optimal caloric intake is important, especially in intensive care units. Resting energy expenditure (REE) for patients with cerebral lesions was estimated between 40 and 200\% higher than a person not injured. This energy expenditure can be reduced with appropriate sedation. ${ }^{36-40}$

Evidence suggests that continuous infusion of sedatives and opioids may increase the duration of mechanical venti- lation (MV) and contributes to pneumonia and ventilator associated bloodstream infections. A strategy to prevent the accumulation of sedatives and opioids is the use of sedatives with daily interruptions and spontaneous breathing attempts to reduce the duration of MV and hospital time. ${ }^{41-50}$

The use of sedation protocols proved effective with a reduction in the duration of MV, hospital stay and use of drugs, but has been limited primarily to medical intensive care unit (ICU) patients. Therefore, a multidisciplinary team is required to develop a protocol for analgesia and sedation, aiming to standardize the process of keeping patients calm and cooperative. ${ }^{26,27}$

The benzodiazepines are central nervous system (CNS) depressants and anticonvulsants, which also increase seizure threshold; they are not painkillers. They stimulate the GABA receptors. This drug act in sedation, anxiolysis, and amnesia effect. The muscle relaxant property is via the spinal cord. It is lipid-soluble and quickly penetrates the bloodbrain barrier. Onset of action is short, producing minimal cardiovascular effects that are contraindicated in hypovolemic patients. ${ }^{51}$ Association of opioids and benzodiazepines are synergies in situations that require a vigorous sedation. If there is high left ventricular pressure, the association of diazepam and midazolam has a "nitroglycerin effect," lowering blood pressure and increasing cardiac output. Drugs in Neurotrauma can decrease the $\mathrm{CBF}$ as well as $\mathrm{CMRO}_{2}$, ICP, and CBV. There is a plateau of maximal effect due to saturation of the receptors. Midazolam may reduce alpha activity, an increased theta and delta- ${ }^{\circledR}$ activity. In the EEG (electroencephalogram). This effect of midazolam will be represented with low voltage in EEG. Midazolam is unable to produce a standard surge suppression in the EEG. It does not affect responses in somatosensory-evoked potential. Midazolam provides greater protection against hypoxia than diazepam. The flumazenil decreases MAP, increases ICP, but has little effect on $\mathrm{CMRO}_{2}{ }^{52-59}$

Opioids have properties similar to morphine. Each receiver has a function. The sigma receptor is related to dysphoria, hallucinations, and respiratory stimulation. The $\mu 1$ relates to analgesia and bradycardia urinary restraint; whereas the $\mu 2$ is responsible for analgesia, respiratory depression, physical dependence, and constipation. The Kappa receptor is related to analgesia, sedation and dysphoria. Finally the DELTA receiver is responsible for analgesia, respiratory depression, physical dependence and urinary retention. Agonists such as pethidine (meperidine), fentanyl and causes less gastric hypomotility, biliary spasm, and has little effect on the breathing pattern. ${ }^{60}$ Synthetic (fentanyl) has high lipid solubility and rapid onset of action without cardiovascular damage. Meperidine increases heart rate. Morphine, fentanyl, sufentanil, alfentanil, remifentanil cause vagus-mediated bradycardia. Meperidine and morphine are histamineinducing, leading to a decrease in blood pressure, systemic vascular resistance, and bronchospasm. Opioids lead to stiffness of the chest wall and increased progressive muscle tone mediated by the $\mu$ receptors in supraspinal muscles in the raphe nucleus and on the bridge. ${ }^{61}$ It provides slower gastric emptying, reducing peristalsis, and biliary spasm. 


\begin{tabular}{|c|c|c|c|c|c|c|}
\hline 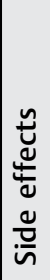 & 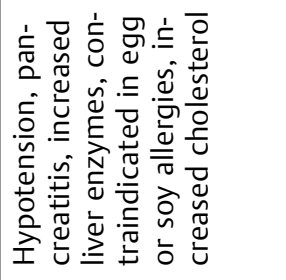 & 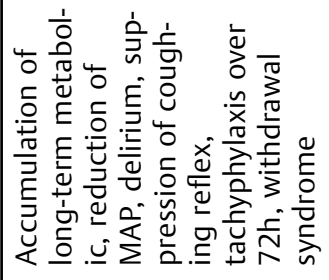 & 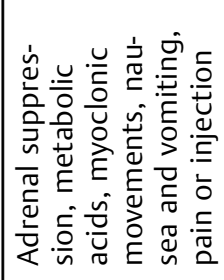 & 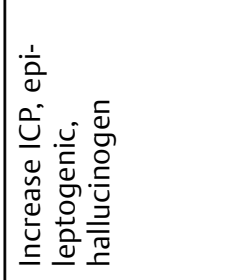 & 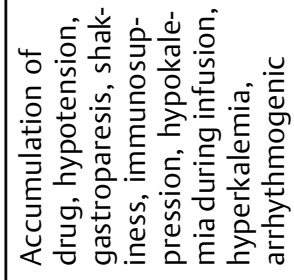 & 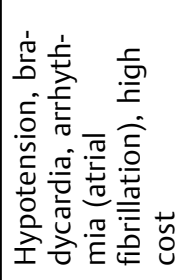 \\
\hline 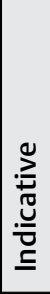 & 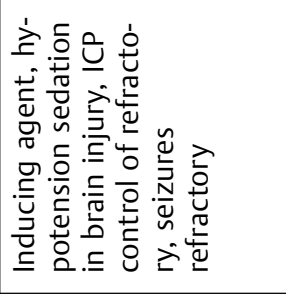 & 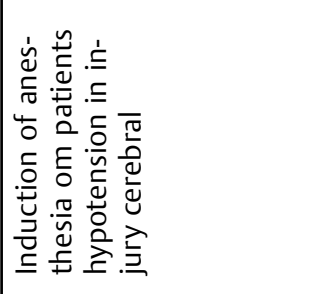 & 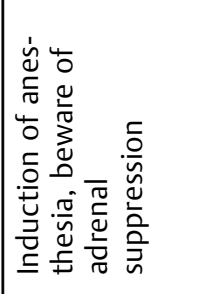 & 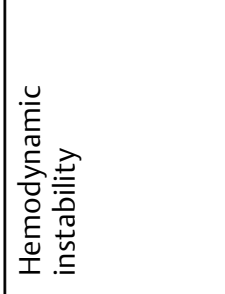 & 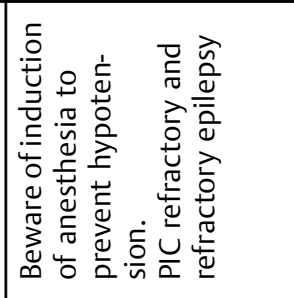 & 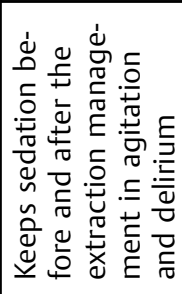 \\
\hline $\begin{array}{l}\tilde{\Delta} \\
\ddot{\Delta}\end{array}$ & 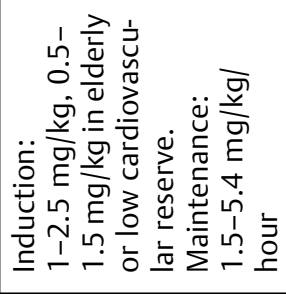 & 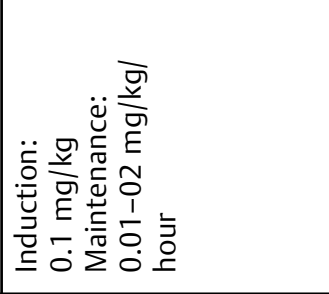 & 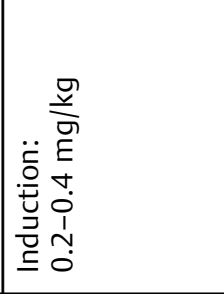 & 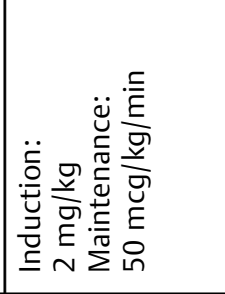 & 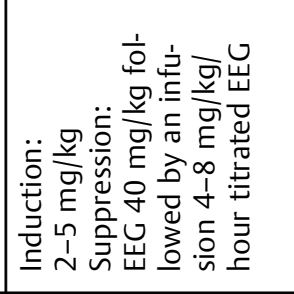 & 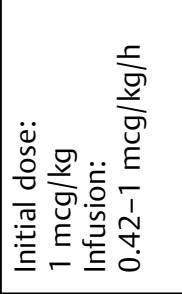 \\
\hline 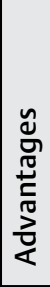 & 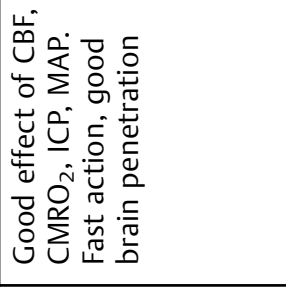 & 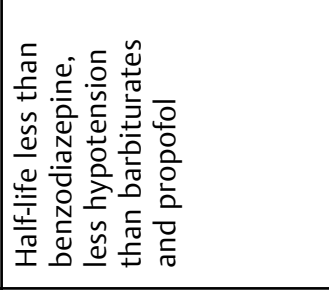 & 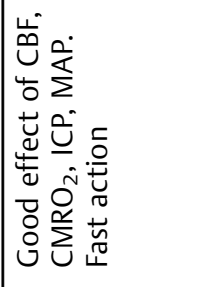 & 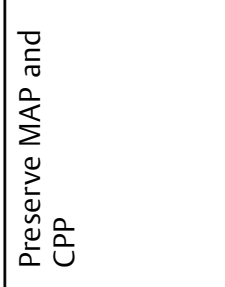 & 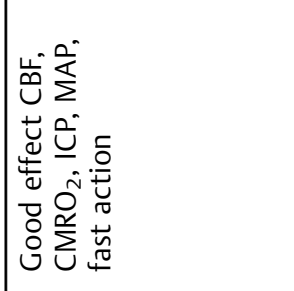 & 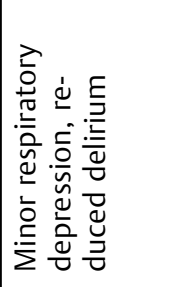 \\
\hline 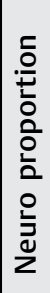 & 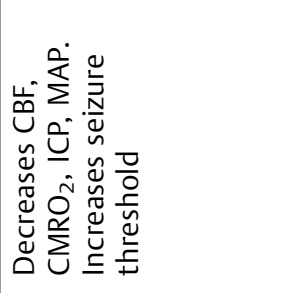 & 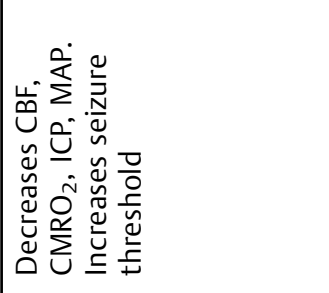 & 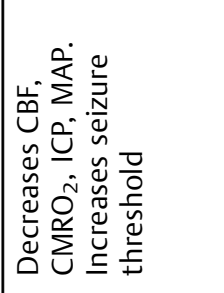 & 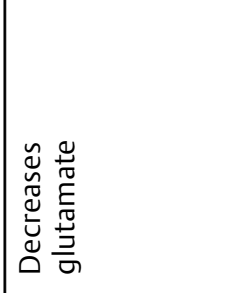 & 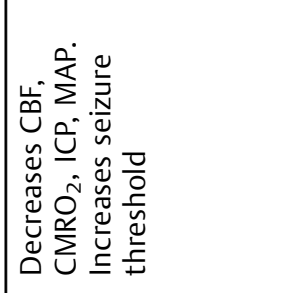 & 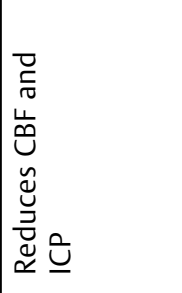 \\
\hline 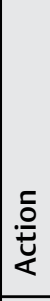 & 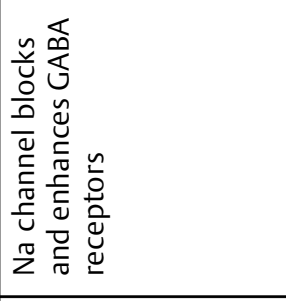 & 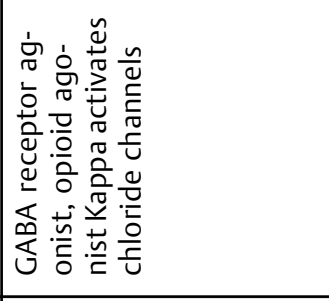 & 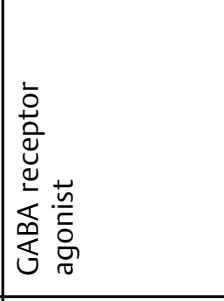 & 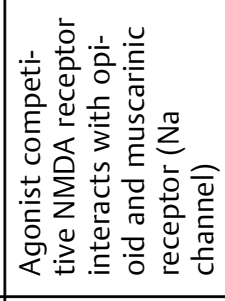 & 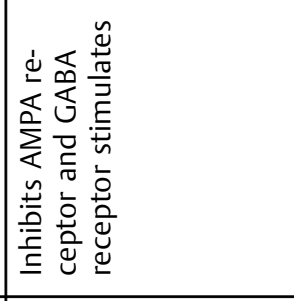 & 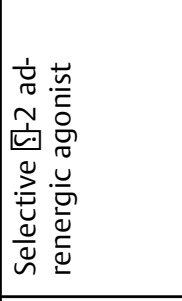 \\
\hline פ & 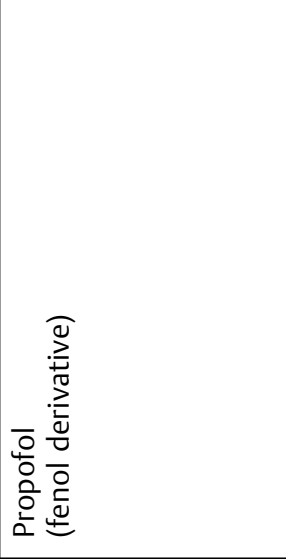 & 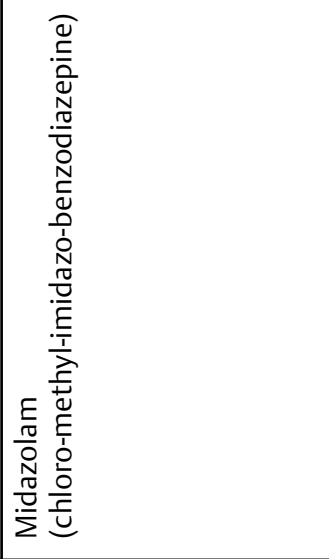 & 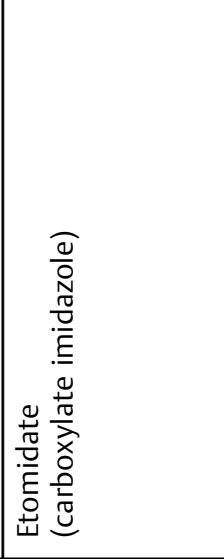 & 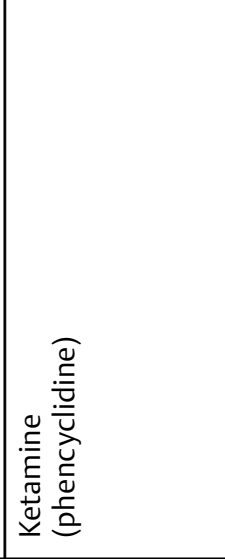 & 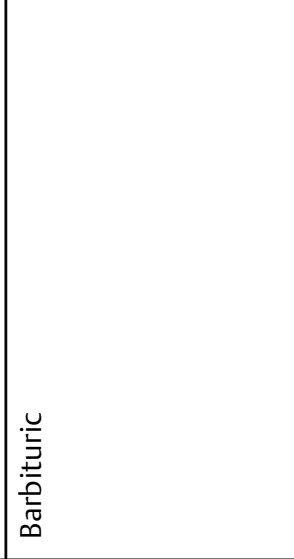 & 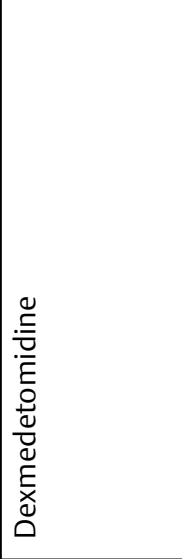 \\
\hline
\end{tabular}




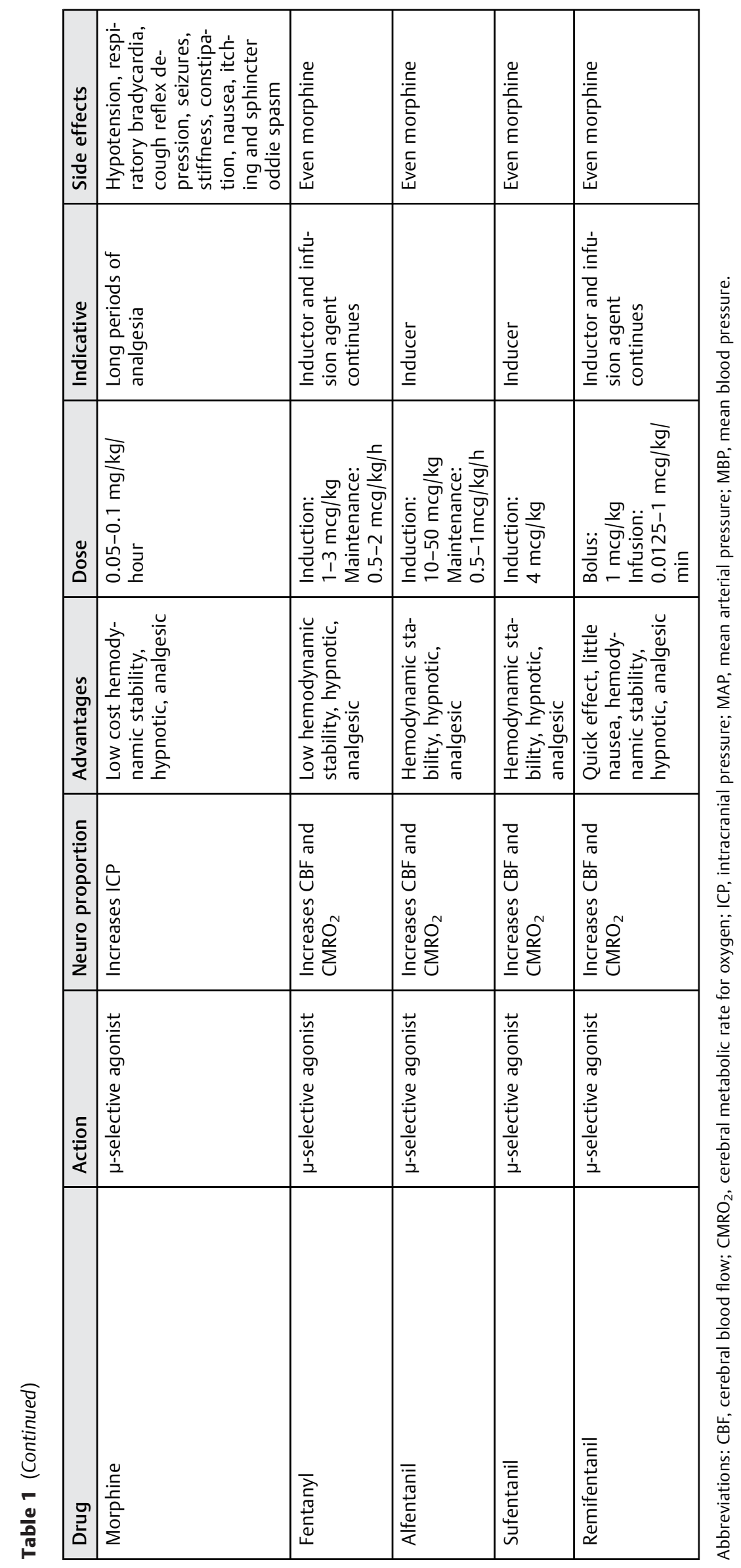


Moreover, it reduces $\mathrm{CMRO}_{2}$, cerebral blood flow, and ICP (intracranial cerebral pressure), reduces MAP and CPP. Sufentanil, alfentanil, and fentanyl in ICP has transient increase in ICP after peak five minutes, returning to normal in 15 minutes. ${ }^{62}$ This transient increase in ICP can lead to muscle stiffness and opioid-induced histamine release. There are few studies on remifentanil, which has significant effects on ICP, with no change in brain metabolic dynamics with rapid awakening. ${ }^{63-67}$

Barbiturates have anticonvulsant properties and cause CNS depression. They activate the GABA receptors and inhibit AMPA excitatory receptors. Thiopental or pentobarbital acts by decreasing ICP, refractory epilepsy, and ischemic protection. These agents are lipophilic, metabolized in the liver by the cytochrome P450. They have a short duration and rapid distribution to fat. Constant EEG monitoring is necessary until there is a pattern of suppression outbreak in EEG. ${ }^{68-75}$

Propofol has high lipid solubility, rapid onset of action, and short half-life of 2 to 8 minutes. Promotes profound decrease in MAP, fall in systemic vascular resistance, cardiac contractility, deep brain depression. Decreases $\mathrm{CMRO}_{2}, \mathrm{CBF}$, and ICP in patients with brain injury. Propofol decreases the release of L-aspartate and L-glutamate. They are plasma antioxidant, useful in neurosurgery patients. Diprivan ${ }^{\mathrm{TM}}$ (Astrazeneca, London, UK), is a special propofol, it contains EDTA as a preservative while the generic product uses sulfides. EDTA is a chelating calcium, which is neuroprotective in combination with propofol. ${ }^{76-86}$

Etomidate has better metabolic behavior in cerebral than barbiturates. Unlike these, etomidate little changes the cardiovascular metabolism. It is lipophilic, with rapid penetration to the brain and other tissue. ${ }^{87}$ The drug is metabolized in blood and liver and excreted in urine (75\%), stool (13\%), and bile (10\%). Its effect on ventilation is minimal. The medication is associated with myoclonus incidence, however, reduce endogenous cortisol production. Supplementation of vitamin C can restore the cortisol levels. It has low solubility in water, resulting from the use of a propylene glycol vehicle, which leads to hyperosmolarity, intravascular hemolysis, renal insufficiency, acidosis, and lactate accumulation. There are records of complications such as thrombophlebitis, phlebitis, and pain on injection. The effect on EEG is equal to that of thiopental. It prolongs survival during hypoxia or ischemia. Glycine and glutamate levels were reduced in the group treated with etomidate. ${ }^{88-91}$

Ketamine interacts with N-methyl-D-aspartate (NMDA) receptor, similar effects can mediate analgesia, inhibiting dorsal horn of spinal cord. This medication of sedative action, amnesia, and analgesic properties increases heart rate, MAP, pulmonary artery pressure increases, hear attack chance and myocardial oxygen consumption, and potent bronchodilator. ${ }^{92}$ Ketamine also increases $\mathrm{CMRO}_{2}$ and ICP. This increase can be blocked by the administration of thiopental or diazepam; combinations are an option in patients with TBI. Midazolam and ketamine association provides small increases in $\mathrm{CBF}$, ICP, and $\mathrm{CMRO}_{2}$; whereas, propofol provides no increase. Ketamine can also lower the seizure threshold. $^{93-97}$
Neuroleptics are of great importance for the control of sedation, anxiolysis, and analgesia. Haloperidol is widely protein binding ( $>90 \%$ ) and metabolized by hepatic glucuronidation that induce ventricular arrhythmias (i.e., Torsade de Pointes), QTi increases, as well as reductions in the relationship between the $\mathrm{CBF}, \mathrm{CMRO} 2$, and ICP. ${ }^{98}$ The clonidine and dexmedetomidine have neuroprotective effects in cerebral ischemia. ${ }^{99-102}$

The halothanes have vasodilatory effect mitigated when associated with intravenous anesthetics that cause cerebral vasoconstriction. ${ }^{103}$

The isoflurane increases CBF less than halothane does. Barbiturates reduce total peripheral resistance, lowering blood pressure, and consequently also decreasing CBF, $\mathrm{CMRO}_{2}$, and ICP, which may depress electrical and ischemic activity. $^{104}$

Lidocaine $(1 \mathrm{mg} / \mathrm{kg}$ ) reduces the ICP and the reflection of tracheal intubation. Although it reduces $\mathrm{CMRO}_{2}$ and $\mathrm{CBF}$, in larger doses it becomes toxic and causes seizures, greatly increasing $\mathrm{CBF}$ and $\mathrm{CMRO}_{2}{ }^{105}$

Neuromuscular blockers are used during mechanical ventilation in patients with severe respiratory insufficiency and in the treatment of patients with intracranial hypertension, avoiding the use of succinylcholine as it may induce increase of intracranial hypertension. They should only be used after adequate sedation and analgesia. The pancuronium curare is preferable for patients with renal function, normal liver, and cardiac and hemodynamic stability. ${ }^{106}$ The vecuronium, on the other hand, should be reserved for patients with heart disease or hemodynamic instability, in which the tachycardia may be deleterious. To avoid tachycardia, it can be used for vecuronium loading dose and pancuronium maintenance. Atracurium should be reserved for patients with renal impairment $(\mathrm{CrCl}<10 \mathrm{~mL} / \mathrm{min})$, and hepatic impairment. (30x greater than the cost of pancuronium). The lock must be monitored with Train-of -Four (TOF). Prophylaxis should be adjusted to high risk of deep venous trombosis (DVT). In curarized patients, the only signs of inadequate sedation can be hypertension, tachycardia, sweating, lacrimation, and mydriasis. In cases that occur with severe intracranial hypertension, the decision to use neuromuscular blockers is still possible. In this case, nondepolarizing is indicated, preferably with less hemodynamic action, such as vecuronium (attack from 0.06 to $0.08 \mathrm{mg} / \mathrm{kg}$, maintenance 0.02 to $0.03 \mathrm{mg} / \mathrm{kg} /$ hour$)$ and atracurium ( 0.3 to $0.5 \mathrm{mg} / \mathrm{kg}$, maintenance 0.2 to $1 \mathrm{mg} / \mathrm{kg}$ / hour), although other agents may be used, such as pancuronium (attack from 0.06 to $0.08 \mathrm{mg} / \mathrm{kg}$, maintenance 0.02 to $0.03 \mathrm{mg} / \mathrm{kg} /$ hour ). When using neuromuscular blockers, it is important to monitor the EEG to avoid convulsive states and, whenever possible, use $t$ a peripheral nerve stimulator. ${ }^{105}$

Nitric oxide $\left(\mathrm{N}_{2} \mathrm{O}\right)$ is used to reduce the consumption of intravenous hypnotic agent and promote patient awakening after surgery, discrete high levels of CBF. Commits brain complacency, increasing this effect in the brain, especially when used with halogenated agent. ${ }^{107,108}$

Dosages and associations can generate their own effects. Thiopental further reduces the $\mathrm{CMRO}_{2}, 50 \%$ of CBF. Fentanyl 
above $200 \mathrm{mcg} / \mathrm{kg}$ increases $\mathrm{CMRO}_{2}, \mathrm{CBF}, \mathrm{PaCO}_{2}$, aside from being epileptogenic. Etomidate in large dosages can lead epileptic seizures. The etomidate and fentanyl association form spicules in the EEG, which may increase seizures. Halogenates reduce $\mathrm{CMRO}_{2}$ and $\mathrm{CBF}$, increase vasodilation, and increase CBV, ICP, which may in turn reduce CPP. ${ }^{109}$ Propofol and midazolam association are beneficial in cerebral hemodynamics, ICP, and CPP. Propofol, however, may lead to hypertriglyceridemia. When reducing bleeding hypotension is required, thiopental or isoflurane decrease total peripheral resistance and blood pressure. Fentanyl, morphine, sufentanil, ketamine, and sufentanil increase the ICP, decreases MAP and CPP. Ketamine and sufentanil have no effect on the MAP. Phenobarbital and etomidate reduce ICP. Propofol and morphine synergistically decrease ICP. Propofol and midazolam has good association. Drugs such as calcium channel blockers, triazole antifungal, and erythromycin inhibit midazolam metabolism. - Table 2 lists the major drugs used for sedation and analgesia in trauma and their relationship with the cerebral dynamics and metabolism. ${ }^{110-112}$

\section{Drug of Choice for Induction for Each Injury}

In neuroanesthesia not just fill the basic requirements such as analgesia, hypnosis, neurovegetative protection and muscle relaxation, should carefully examine each disease. ${ }^{111,112}$

Cerebral aneurysm, ischemia may occur by vasospasm should be careful with hypotension. When autoregulation is compromised will be difficulties in reducing CBV with hearing impairment. If necessary blood temporary occlusion, cerebral protection measures are necessary. if not clipped all aneurysms should be careful with hypertension, because the risk of rerupt. ${ }^{97}$

In brain tumor resections may have alteration of cardiovascular, respiratory and level of consciousness. When extensive peritumoral area with compromised edema or selfregulation, there may be difficulty in reducing brain volume through anesthetic maneuvers. The bleeding in the tumor area after resection, we need mild hypotension regime in the immediate postoperative period. ${ }^{113}$
If the ICP is high, there may be cardiovascular changes at the decompression. ${ }^{114}$ Traumatic brain injury as the worst Glasgow more likely to be little vascular reactivity. ${ }^{114}$

In spinal cord injury may experience difficulty ventilatory due to lack of movement of the chest muscles, indicating immediate endotracheal intubation and mechanical ventilation to prevent hypoxemia. The friendly spinal injury high level exacerbates the parasympathetic activity and at the time of tracheal intubation may occur reflex bradycardia and cardiac arrest. The total peripheral vasoplegia, due to the sympathetic injury, causing significant hypotension. In this situation hypotension should be corrected with volume infusion associated with vasopressor drug titrated way, and should avoid the use of anesthetics that cause depression of the cardiovascular system.

With the exception burnt, intravenous drugs reduce the $\mathrm{CBF}$ and $\mathrm{CMRO}_{2}$, which is a good indication for patients with high ICP because they reduce CBV. On the other hand fully intravenous anesthetic technique choice may hinder the early awakening of the patient difficult neurological evaluation. ${ }^{115-117}$

Resection of AVM (arterial venous malformation) produces a reduction in bleeding on the bed where he was the AVM, this is achieved by hypotension. Resection causes the blood flow before passing the AVM passes by passing pathological vessels that do not have effective self-regulation. This increased supply, increases the flow of pathological vessels and may have brain barrier break and brain swelling and increased ICP. In this situation the barbiturate is well indicated, until it can awaken without hypertension and bleeding. The barbiturate coma reduce the consumption of oxygen brain and will contract non pathological brain vessels, reducing ICP. Barbiturate large dose (4-5 g / 24 hours), depress the cardiovascular system that reduces cardiac output and the total peripheral resistance, causing hypotension arterial. ${ }^{118}$

After blood temporary arterial occlusion brain for a long time, with the use of hypothermia, the patient may experience respiratory difficulty in the immediate postoperative period. This difficulty may be caused by temporary ischemia due to arterial occlusion or metabolic changes inherent to

Table 2 Drug ratio most used for sedation and analgesia, and the effects on the cerebral metabolism

\begin{tabular}{|l|l|l|l|l|l|l|l|l|l|}
\hline Drug & ICP & CPP & $\mathrm{CMRO}_{2}$ & $\mathrm{CBF}$ & MAP & $\begin{array}{l}\text { Epilepsy } \\
\text { action }\end{array}$ & $\begin{array}{l}\text { ICP } \\
\text { prevention }\end{array}$ & Sedation & Analgesia \\
\hline Morphine & $\geq$ & $\leq$ & $=$ & 0 & - & 0 & + & + & + \\
\hline Benzodiazepine & $\geq$ & $\leq$ & $=$ & $\leq$ & - & + & + & + & +++ \\
\hline Propofol & $\leq$ & $\leq$ & $<$ & $\leq$ & -- & + & + & ++ \\
\hline Barbituric & -- & $\leq$ & $<$ & -- & -- & + & + & + & +++ \\
\hline Etomidate & $\leq$ & $=$ & $<$ & - & 0 & 0 & + & ++ & + \\
\hline Curare & $\leq$ & $=$ & 0 & 0 & 0 & 0 & + & + & + \\
\hline Ketamine & $\leq$ & $=$ & $=$ & 0 & 0 & 0 & + & + \\
\hline
\end{tabular}

Abbreviations: $\mathrm{CBF}$, cerebral blood flow; $\mathrm{CMRO}_{2}$, cerebral metabolic rate for oxygen; ICP, intracranial pressure; MAP, mean arterial pressure; CPP, cerebral perfusion pressure; 0 , without contributions; + , increase; ++ , significant increase; +++ , more significant increase -, reduction; - -, significant reduction; - - -, more significant reduction. 
142 Sedation and Analgesia in Severe Head Trauma Rabelo et al.

hypothermic, dehydration and the use of anesthetic large quantidade. $^{118}$

Tumors in the hypothalamus region of stem and bulb, near lower cranial nerves, usually have cardiorespiratory problems in the postoperative period.

Patients with pulmonary disease, obese, with breathing difficulties and patients with multiple associated diseases that increase postoperative morbidity, should be kept intubated. Should choose drugs that have fast metabolism and excretion, as propofol, etomidate and analgesics short duração. ${ }^{118}$

\section{Ideal Sedation for Neurocritical Patients}

The medications for optimal sedation of neurocritical patients must start and end fast, as well as provide predictability of action to target organs, be easily titrated, and able to reduce ICP by reducing blood volume or cerebral vasoconstriction, reducing $\mathrm{CBF}$ and $\mathrm{CMRO}_{2}$. At the same time, they must keep the $\mathrm{CBF} / \mathrm{CMRO}_{2}$ combination, maintain cerebral autoregulation, allowing cerebrovascular reactivity variations of $\mathrm{PaCO}_{2}$, minimal cardiovascular depression, brain tissue recovery, and prevent secondary neuronal damage. This allows neurological evaluation, limiting the stress response to critical illness, protecting the brain during ischemia by metabolic depression, attenuating the release of catecholamines induced by ischemia, increasing vascular resistance of non-ischemic areas, increasing glucose plasma a2-adrenergic inhibition by insulin. Patients using these drugs need to be monitored through the use of capnography, ICP, MAP, CPP, transcranial Doppler. The level of sedation and adaptations to fan can be monitored by clinical parameters such as SAS, RASS, Ramsay, and Glasgow scales. Use of BIS

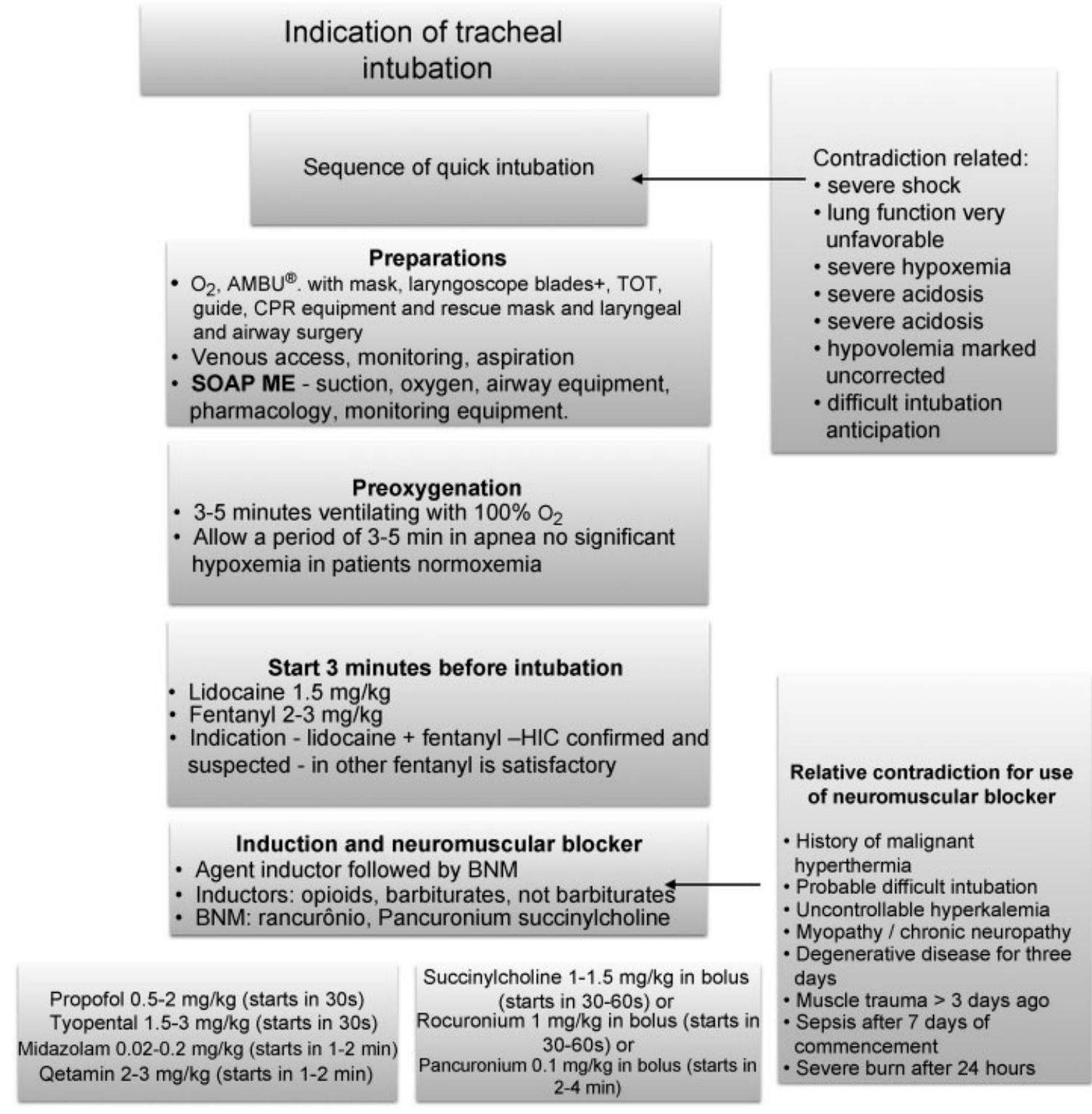

Fig. 1 Algorithm intubation in the emergency room. Abbreviations: AMBU ${ }^{\circledR}$, bag valve mask; BNM, neuromuscular block, CPR, cardiopulmonary resuscitation; TOT, endotracheal intubation. 
(Bispectral index) has been of great value for monitoring sedation since it encodes the EEG traces into digital values ranging from 0 to 100 . Values between 90 and 100 mean the patient is awake and between 45 and 60 means the patient is adequately anesthetized. ${ }^{113-120}$

The pharmacokinetics of drugs depends of absorption, distribution, metabolism or biotransformation, and excretion of drugs. In brain injury, disruption of the blood-brain barrier and changes in the binding protein can modify the drugś pharmacokinetics. Perfused organs receive disproportionately large amounts of the drug compared with poorly perfused organs. The elimination of the drug occurs in two stages. First occurs through oxidation and reduction reactions, cytochrome P-450 and hydrolytic reactions. Second is through conjugation reactions of the drug or its metabolite with an endogenous substrate, such as D-glucuronic acid. The drugs cross biologic membranes. The kidney is the main excretor. ${ }^{119-121}$

One study found that pre-hospital intubation may increase mortality. Mortality of intubated patients in trauma scene was $93 \%$, compared with $67 \%$ mortality that were intubated in hospital. This statistic persists even when adjusted for age, Glasgow score, associated injuries, and injury mechanism. The increased mortality pre-hospital is due to lower staff training regarding the rapid sequence intubation procedure and the greater frequency of more severe patients in pre-hospital care. The bias of this study is the selection bias of patients since patients scene end up being worse. ${ }^{118,119}$

The anticonvulsant action of sedatives is widely used in clinical practice. Risk factors for early posttraumatic seizures are: Glasgow below 10, injury, subdural or epidural hematoma, penetrating injury, and convulsions in the first 24 hours. The drugs with superior results were barbiturates, propofol, and benzodiazepines. Early prevention of seizure does not diminish late epilepsy after trauma. Phenytoin and carbamazepine are also very effective in the seizure post early trauma prevention. ${ }^{121-125}$

Neurological patients often present autonomic disorders. Sedatives and analgesics, as well as neuroleptics, can

\section{Intracranial hypertension algorithm}

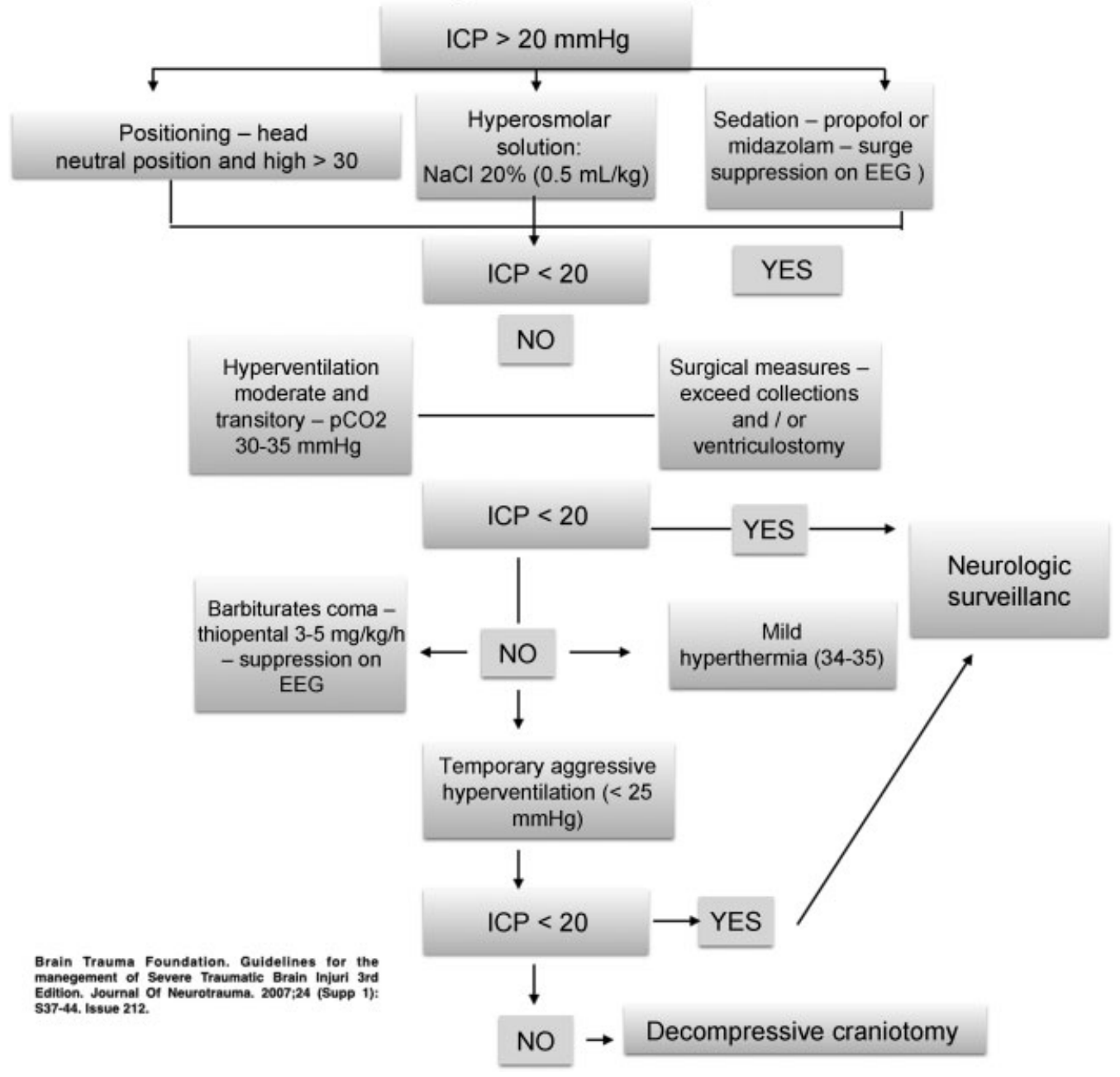

Fig. 2 Algorithm for treatment of patients with intracranial pressure in the emergency room. Abbreviations: EEG (electroencephalogram); ICP (intracranial pressure). Source: Brain Trauma Foundation. Guidelines for the management of severe traumatic brain injury. J Neurotrauma 2007; 24(Suppl1):s37-s44. 
contribute for treatment. The main usage of medications that avoid hypertension, tachycardia, tachypnea, hyperthermia, sweating triggered by autonomic disorders, and their effects on the central nervous system. ${ }^{126}$

Discuss in this paper the non-pharmacological sedation procedure to help these patients. It involves respect family / patient / staff. Decreased volume monitoring equipment, active and passive mobilization of the patient, respecting the circadian cycle, family stay with patient and even use personal songs in hospital. ${ }^{127}$

The reversal of drugs frequently occurs in neurological patients. Neuromuscular blockers reverse with Prostigmine ${ }^{\circledR}(0.25$ to $0.35 \mathrm{mg} / \mathrm{kg})$ and atropine $(20 \mathrm{mg} / \mathrm{kg})$, which can increase the ICP. The flumazenil ( 0.1 to $0.4 \mathrm{mg} / \mathrm{kg}$ ) used to reverse the benzodiazepines may cause tachycardia, hypertension, and increase $\mathrm{CMRO}_{2}$. The naloxone ( 0.4 to $2 \mathrm{mg}$ ) to reversal opioids. Benzodiazepines may lead to reactive bilateral mydriasis. The treatment uses up morphine or methadone or clonidine associated to treatment with anxiolytics and sedatives.

Neuronal activity and apoptosis are stimulated by electrical activity of the brain on NMDA receptors in two ways depending on the receiver's position in the cell. Synaptic are neuroprotective, related to neuronal activity. The extrasynaptic NMDA receptors are related to cell death or reduction of neuronal activity and decrease of CPP and MAP. ${ }^{89}$ Deep sedation reduces neuronal activity, loss of neurons, and functional neurological impairment. Tissue repair after acute brain injury occurs when there are activation mechanisms of brain development. Deprivation of neural activity with anticonvulsants also had adverse effects after brain injury with stimulation of extrasynaptic receptors. Pretreatment with midazolam or isoflurane can lead to cell death and worse results in rats acutely brain injury.

This paper contributes to the literature with two algorithms, presented in -Figs. 1 and 2, regarding the medications used in rapid sequence intubation and management of intracranial hypertension.

\section{Conclusion}

A range of sedative and analgesic agents are available for sedation. Each class has its own positive and negative effects in critically ill neurotrauma patients. There are few studies, which are limited to tests performed during elective neurosurgical procedures or in healthy volunteers in the brain metabolism works on physiological thresholds. Thus, data must be applied cautiously for neurocritical patients. The preference for certain agents should be based on a thorough understanding of the effects on brain metabolism and intracranial compliance. The ideal medication is one that combines reduced LCR, increase less CBF and CBV, increase CPP, and decrease the IPC without much decrease to MAP. It is best to avoid the use of inhaled halogenates since they vasodilate the brain, which worsens the brain hemodynamics. It is preferable to use intravenous sedatives. The target for the use of these agents is to optimize the care of critically ill patients in neurotrauma without affecting the ability to assess the patient clinically to limit the secondary neuronal damage due to pain agitation and sedation. The correct analysis of sedation medications and analgesia in neurotrauma, with rapid sequence intubation and management of medications in intracranial hypertension, provide a correct handling in the brain.

\section{References}

1 Blamoun J, Alfakir M, Rella ME, et al. Efficacy of an expanded ventilator bundle for the reduction of ventilator-associated pneumonia in the medical intensive care unit. Am J Infect Control 2009;37(2):172-175

2 Kanouff AJ, DeHaven KD, Kaplan PD. Prevention of nosocomial infections in the intensive care unit. Crit Care Nurs Q 2008;31(4): 302-308

3 Girard TD, Kress JP, Fuchs BD, et al. Efficacy and safety of a paired sedation and ventilator weaning protocol for mechanically ventilated patients in intensive care (Awakening and Breathing Controlled trial): a randomised controlled trial. Lancet 2008; 371(9607):126-134

4 Nasraway SA Jr, Jacobi J, Murray MJ, Lumb PD; Task Force of the American College of Critical Care Medicine of the Society of Critical Care Medicine and the American Society of HealthSystem Pharmacists, American College of Chest Physicians. Sedation, analgesia, and neuromuscular blockade of the critically ill adult: revised clinical practice guidelines for 2002. Crit Care Med 2002;30(1):117-118

5 Strøm T, Martinussen T, Toft P. A protocol of no sedation for critically ill patients receiving mechanical ventilation: a randomised trial. Lancet 2010;375(9713):475-480

6 Jacobi J, Fraser GL, Coursin DB, et al; Task Force of the American College of Critical Care Medicine (ACCM) of the Society of Critical Care Medicine (SCCM), American Society of Health-System Pharmacists (ASHP), American College of Chest Physicians. Clinical practice guidelines for the sustained use of sedatives and analgesics in the critically ill adult. Crit Care Med 2002;30(1):119-141

7 Brook AD, Ahrens TS, Schaiff R, et al. Effect of a nursingimplemented sedation protocol on the duration of mechanical ventilation. Crit Care Med 1999;27(12):2609-2615

8 Robinson BR, Mueller EW, Henson K, Branson RD, Barsoum S, Tsuei BJ. An analgesia-delirium-sedation protocol for critically ill trauma patients reduces ventilator days and hospital length of stay. J Trauma 2008;65(3):517-526

9 de Wit M, Gennings C, Jenvey WI, Epstein SK. Randomized trial comparing daily interruption of sedation and nursing-implemented sedation algorithm in medical intensive care unit patients. Crit Care 2008;12(3):R70

10 Mattia C, Savoia G, Paoletti F, et al; SIAARTI. SIAARTI recommendations for analgo-sedation in intensive care unit. Minerva Anestesiol 2006;72(10):769-805

11 Gandevia B, Tovell A. Declaration of Helsinki. Med J Aust 1964; 2:320-321

12 Jensen MP, Karoly P, O'Riordan EF, Bland F Jr, Burns RS. The subjective experience of acute pain. An assessment of the utility of 10 indices. Clin J Pain 1989;5(2):153-159

13 Puntillo KA, White C, Morris AB, et al. Patients' perceptions and responses to procedural pain: results from Thunder Project II. Am J Crit Care 2001;10(4):238-251

14 Ely EW, Truman B, Shintani A, et al. Monitoring sedation status over time in ICU patients: reliability and validity of the Richmond Agitation-Sedation Scale (RASS). JAMA 2003;289(22): 2983-2991

15 Sessler CN, Gosnell MS, Grap MJ, et al. The Richmond AgitationSedation Scale: validity and reliability in adult intensive care 
unit patients. Am J Respir Crit Care Med 2002;166(10): 1338-1344

16 Payen JF, Chanques G, Mantz J, et al. Current practices in sedation and analgesia for mechanically ventilated critically ill patients: a prospective multicenter patient-based study. Anesthesiology 2007;106(4):687-695, quiz 891-892

17 Knaus WA, Draper EA, Wagner DP, Zimmerman JE. APACHE II: a severity of disease classification system. Crit Care Med 1985; 13(10):818-829

18 Vincent JL, de Mendonça A, Cantraine F, et al. Use of the SOFA score to assess the incidence of organ dysfunction/failure in intensive care units: results of a multicenter, prospective study. Working group on "sepsis-related problems" of the European Society of Intensive Care Medicine. Crit Care Med 1998;26(11): 1793-1800

19 Kollef MH, Levy NT, Ahrens TS, Schaiff R, Prentice D, Sherman G. The use of continuous i.v. sedation is associated with prolongation of mechanical ventilation. Chest 1998;114(2):541-548

20 Kress JP, Pohlman AS, O'Connor MF, Hall JB. Daily interruption of sedative infusions in critically ill patients undergoing mechanical ventilation. N Engl J Med 2000;342(20):1471-1477

21 Weisbrodt L, McKinley S, Marshall AP, Cole L, Seppelt IM, Delaney A. Daily interruption of sedation in patients receiving mechanical ventilation. Am J Crit Care 2011;20(4):e90-e98

22 Youngquist P, Carroll M, Farber M, et al. Implementing a ventilator bundle in a community hospital. Jt Comm J Qual Patient Saf 2007;33(4):219-225

23 Augustes R, Ho KM. Meta-analysis of randomised controlled trials on daily sedation interruption for critically ill adult patients. Anaesth Intensive Care 2011;39(3):401-409

24 Shehabi Y, Weisbrodt L. Daily sedation interruption; a glass half empty? Anaesth Intensive Care 2011;39(3):339-341

25 Martin J, Heymann A, Bäsell K, et al. Evidence and consensusbased German guidelines for the management of analgesia, sedation and delirium in intensive care-short version. Ger Med Sci 2010;8:Doc02

26 Lütz A, Spies C. [ICU delirium: Consequences for management of analgesia and sedation in the critically ill]. Anasthesiol Intensivmed Notfallmed Schmerzther 2011;46(9):568-572

27 Bayat A, Arscott G. Continuous intravenous versus bolus parenteral midazolam: a safe technique for conscious sedation in plastic surgery. Br J Plast Surg 2003;56(3):272-275

28 Arias-Rivera S, Sánchez-Sánchez MM, Sánchez-Izquierdo R, Gallardo-Murillo MJ, Santos-Díaz RI, Frutos-Vivar F. [Establishment of a nursing-driven sedation protocol: effect on the sedation level and accidental withdrawal of tubes and catheters]. Enferm Intensiva 2008;19(2):71-77

29 Marshall J, Finn CA, Theodore AC. Impact of a clinical pharmacistenforced intensive care unit sedation protocol on duration of mechanical ventilation and hospital stay. Crit Care Med 2008; 36(2):427-433

30 Horn E, Nesbit SA. Pharmacology and pharmacokinetics of sedatives and analgesics. Gastrointest Endosc Clin N Am 2004; 14(2):247-268

31 Egerod I, Christensen BV, Johansen L. Trends in sedation practices in Danish intensive care units in 2003: a national survey. Intensive Care Med 2006;32(1):60-66

32 Roberts R, Ruthazer R, Chi A, et al. Impact of a national propofol shortage on duration of mechanical ventilation at an academic medical center. Crit Care Med 2012;40(2):406-411

33 Polderman $\mathrm{KH}$. Induced hypothermia and fever control for prevention and treatment of neurological injuries. Lancet 2008;371(9628):1955-1969

34 Nolan JP, Deakin CD, Soar J, Böttiger BW, Smith G; European Resuscitation Council. European Resuscitation Council guidelines for resuscitation 2005. Section 4. Adult advanced life support. Resuscitation 2005;67(Suppl 1):S39-S86
35 Peberdy MA, Callaway CW, Neumar RW, et al; American Heart Association. Part 9: post-cardiac arrest care; 2010 American Heart Association Guidelines for cardiopulmonary resuscitation and emergency cardiovascular care. Circulation 2010;122(18, Suppl 3):S768-S786

36 Giner M, Laviano A, Meguid MM, Gleason JR. In 1995 a correlation between malnutrition and poor outcome in critically ill patients still exists. Nutrition 1996;12(1):23-29

37 Wilson RF, Tyburski JG. Metabolic responses and nutritional therapy in patients with severe head injuries. J Head Trauma Rehabil 1998;13(1):11-27

38 The Brain Trauma Foundation. The Brain Trauma Foundation. The American Association of Neurological Surgeons. The Joint Section on Neurotrauma and Critical Care. Nutrition. J Neurotrauma 2000;17(6-7):539-547

39 Damask MC, Weissman C, Askanazi J, Hyman AI, Rosenbaum SH, Kinney JM. A systematic method for validation of gas exchange measurements. Anesthesiology 1982;57(3):213-218

40 Epstein CD, Peerless JR, Martin JE, Malangoni MA. Comparison of methods of measurements of oxygen consumption in mechanically ventilated patients with multiple trauma: the Fick method versus indirect calorimetry. Crit Care Med 2000;28(5): 1363-1369

41 Pepe JL, Barba CA. The metabolic response to acute traumatic brain injury and implications for nutritional support. J Head Trauma Rehabil 1999;14(5):462-474

42 Frankenfield D. Energy expenditure and protein requirements after traumatic injury. Nutr Clin Pract 2006;21(5):430-437

43 Krakau K, Omne-Pontén M, Karlsson T, Borg J. Metabolism and nutrition in patients with moderate and severe traumatic brain injury: A systematic review. Brain Inj 2006;20(4):345-367

44 Raurich JM, Ibáñez J. Metabolic rate in severe head trauma. JPEN J Parenter Enteral Nutr 1994;18(6):521-524

45 Clifton GL, Robertson CS, Choi SC. Assessment of nutritional requirements of head-injured patients. J Neurosurg 1986;64(6): 895-901

46 Sunderland PM, Heilbrun MP. Estimating energy expenditure in traumatic brain injury: comparison of indirect calorimetry with predictive formulas. Neurosurgery 1992;31(2):246-252, discussion 252-253

47 Bratton SL, Chestnut RM, Ghajar J, et al; Brain Trauma Foundation; American Association of Neurological Surgeons; Congress of Neurological Surgeons; Joint Section on Neurotrauma and Critical Care, AANS/CNS. Guidelines for the management of severe traumatic brain injury. XII. Nutrition. J Neurotrauma 2007;24(Suppl 1):S77-S82

48 Terao Y, Miura K, Saito M, Sekino M, Fukusaki M, Sumikawa K. Quantitative analysis of the relationship between sedation and resting energy expenditure in postoperative patients. Crit Care Med 2003;31(3):830-833

49 Bruder N, Raynal M, Pellissier D, Courtinat C, François G. Influence of body temperature, with or without sedation, on energy expenditure in severe head-injured patients. Crit Care Med 1998;26(3):568-572

50 Barton RG, Craft WB, Mone MC, Saffle JR. Chemical paralysis reduces energy expenditure in patients with burns and severe respiratory failure treated with mechanical ventilation. J Burn Care Rehabil 1997;18(5):461-468, discussion 460

51 Marik PE, Kaufman D. The effects of neuromuscular paralysis on systemic and splanchnic oxygen utilization in mechanically ventilated patients. Chest 1996;109(4):1038-1042

52 Albert PS. Longitudinal data analysis (repeated measures) in clinical trials. Stat Med 1999;18(13):1707-1732

53 Bucknall TK, Manias E, Presneill JJ. A randomized trial of protocol-directed sedation management for mechanical ventilation in an Australian intensive care unit. Crit Care Med 2008;36(5): 1444-1450 
54 Dasta JF, Kane-Gill S. Pharmacoeconomics of sedation in the ICU. Crit Care Clin 2009;25(3):571-583, ix ix

55 Elliott R, McKinley S, Aitken LM, Hendrikz J. The effect of an algorithm-based sedation guideline on the duration of mechanical ventilation in an Australian intensive care unit. Intensive Care Med 2006;32(10):1506-1514

56 Ely EW, Inouye SK, Bernard GR, et al. Delirium in mechanically ventilated patients: validity and reliability of the confusion assessment method for the intensive care unit (CAM-ICU). JAMA 2001a286(21):2703-2710

57 Ely EW, Margolin R, Francis J, et al. Evaluation of delirium in critically ill patients: validation of the Confusion Assessment Method for the Intensive Care Unit (CAM-ICU). Crit Care Med 2001b29(7):1370-1379

58 Olsson T, Asplund K, Hägg E. Pituitary-thyroid axis, prolactin and growth hormone in patients with acute stroke. J Intern Med 1990;228(3):287-290

59 Gélinas C, Johnston C. Pain assessment in the critically ill ventilated adult: validation of the Critical-Care Pain Observation Tool and physiologic indicators. Clin J Pain 2007;23(6):497-505

60 Manthous CA, Hall JB, Kushner R, Schmidt GA, Russo G, Wood LD. The effect of mechanical ventilation on oxygen consumption in critically ill patients. Am J Respir Crit Care Med 1995;151(1): 210-214

61 Savard JF, Faisy C, Lerolle N, Guerot E, Diehl JL, Fagon JY. Validation of a predictive method for an accurate assessment of resting energy expenditure in medical mechanically ventilated patients. Crit Care Med 2008;36(4):1175-1183

62 Brosh A. Heart rate measurements as an index of energy expenditure and energy balance in ruminants: a review. J Anim Sci 2007;85(5):1213-1227

63 Mehta S, Burry L, Martinez-Motta JC, et al; Canadian Critical Care Trials Group. A randomized trial of daily awakening in critically ill patients managed with a sedation protocol: a pilot trial. Crit Care Med 2008;36(7):2092-2099

64 Guenther U, Popp J, Koecher L, et al. Validity and reliability of the CAM-ICU Flowsheet to diagnose delirium in surgical ICU patients. J Crit Care 2010;25(1):144-151

65 Gueorguieva R, Krystal JH. Move over ANOVA: progress in analyzing repeated-measures data and its reflection in papers published in the Archives of General Psychiatry. Arch Gen Psychiatry 2004;61(3):310-317

66 Hedeker DR, Gibbons RD. Longitudinal data analysis. Hoboken, NJ: John Wiley \& Sons; 2006

67 Hooper MH, Girard TD. Sedation and weaning from mechanical ventilation: linking spontaneous awakening trials and spontaneous breathing trials to improve patient outcomes. Crit Care Clin 2009;25(3):515-525, viii viii

68 Arias-Rivera S, Sánchez-Sánchez MdelM, Santos-Díaz R, et al. Effect of a nursing-implemented sedation protocol on weaning outcome. Crit Care Med 2008;36(7):2054-2060

69 Kress JP, Gehlbach B, Lacy M, Pliskin N, Pohlman AS, Hall JB. The long-term psychological effects of daily sedative interruption on critically ill patients. Am J Respir Crit Care Med 2003;168(12): 1457-1461

70 McCall M, Jeejeebhoy K, Pencharz P, Moulton R. Effect of neuromuscular blockade on energy expenditure in patients with severe head injury. JPEN J Parenter Enteral Nutr 2003;27(1):27-35

71 Kress JP, Vinayak AG, Levitt J, et al. Daily sedative interruption in mechanically ventilated patients at risk for coronary artery disease. Crit Care Med 2007;35(2):365-371

72 Little RJA, Rubin DB. Statistical analysis with missing data. 2nd ed. Hoboken, NJ: Wiley-Interscience; 2002

73 McKnight PE, McKnight KM, Sidani S, Figueredo AJ. Missing data: a gentle introduction. New York, NY: Guilford Press; 2007

74 Michaels AJ. Management of post traumatic respiratory failure. Crit Care Clin 2004;20(1):83-99, vi-vii vi -vii
75 O'Connor M, Bucknall T, Manias E. A critical review of daily sedation interruption in the intensive care unit. J Clin Nurs 2009; 18(9):1239-1249

76 Payen JF, Bru O, Bosson JL, et al. Assessing pain in critically ill sedated patients by using a behavioral pain scale. Crit Care Med 2001;29(12):2258-2263

77 Georgiadis D, Schwarz S, Baumgartner RW, Veltkamp R, Schwab $S$. Influence of positive end-expiratory pressure on intracranial pressure and cerebral perfusion pressure in patients with acute stroke. Stroke 2001;32(9):2088-2092

78 Schafer JL, Graham JW. Missing data: our view of the state of the art. Psychol Methods 2002;7(2):147-177

79 Schweickert WD, Gehlbach BK, Pohlman AS, Hall JB, Kress JP. Daily interruption of sedative infusions and complications of critical illness in mechanically ventilated patients. Crit Care Med 2004;32(6):1272-1276

80 Huynh T, Messer M, Sing RF, Miles W, Jacobs DG, Thomason MH. Positive end-expiratory pressure alters intracranial and cerebral perfusion pressure in severe traumatic brain injury. J Trauma 2002;53(3):488-492, discussion 492-493

81 Sessler CN, Pedram S. Protocolized and target-based sedation and analgesia in the ICU. Crit Care Clin 2009;25(3):489-513, viii viii

82 Singer JD, Willett JB. Applied longitudinal data analysis: modeling change and event occurrence. New York, NY: Oxford University Press; 2003

83 Tanios MA, de Wit M, Epstein SK, Devlin JW. Perceived barriers to the use of sedation protocols and daily sedation interruption: a multidisciplinary survey. J Crit Care 2009;24(1):66-73

84 Tobar E, Romero C, Galleguillos T, et al. [Confusion Assessment Method for diagnosing delirium in ICU patients (CAM-ICU): cultural adaptation and validation of the Spanish version]. Med Intensiva 2010;34(1):4-13

85 Vanderbilt University. . El Método para la Evaluación de la Confusión en la UCI (CAM-ICU) [The Confusion Assessment Method for the ICU (CAM-ICU)]; 2002, Available at: http:// www.icudelirium.org/docs/CAM ICU training Spanish.pdf 06/ 12/2015. Access on Aug 5, 2015

86 Brucia J, Rudy E. The effect of suction catheter insertion and tracheal stimulation in adults with severe brain injury. Heart Lung 1996;25(4):295-303

87 Lemson J, Driessen JJ, van der Hoeven JG. The effect of neuromuscular blockade on oxygen consumption in sedated and mechanically ventilated pediatric patients after cardiac surgery. Intensive Care Med 2008;34(12):2268-2272

88 Sessler CN, Varney K. Patient-focused sedation and analgesia in the ICU. Chest 2008;133(2):552-565

89 Sanchez-Izquierdo-Riera JA, Caballero-Cubedo RE, Perez-Vela JL, Ambros-Checa A, Cantalapiedra-Santiago JA, Alted-Lopez E. Propofol versus midazolam: safety and efficacy for sedating the severe trauma patient. Anesth Analg 1998;86(6):1219-1224

90 Kress JP, Hall JB. Sedation in the mechanically ventilated patient. Crit Care Med 2006;34(10):2541-2546

91 Lauer KK, Connolly LA, Schmeling WT. Opioid sedation does not alter intracranial pressure in head injured patients. Can J Anaesth 1997;44(9):929-933

92 Bruder N, Lassegue D, Pelissier D, Graziani N, François G. Energy expenditure and withdrawal of sedation in severe head-injured patients. Crit Care Med 1994;22(7):1114-1119

93 Albanèse J, Viviand X, Potie F, Rey M, Alliez B, Martin C. Sufentanil, fentanyl, and alfentanil in head trauma patients: a study on cerebral hemodynamics. Crit Care Med 1999;27(2): 407-411

94 Kelly DF, Goodale DB, Williams J, et al. Propofol in the treatment of moderate and severe head injury: a randomized, prospective double-blinded pilot trial. J Neurosurg 1999; 90(6):1042-1052 
95 Todd MM, Warner DS. A comfortable hypothesis reevaluated. Cerebral metabolic depression and brain protection during ischemia. Anesthesiology 1992;76(2):161-164

96 Albanèse J, Garnier F, Bourgoin A, Léone $M$. The agents used for sedation in neurointensive care unit. Ann Fr Anesth Reanim 2004;23(5):528-534

97 Ward JD, Becker DP, Miller JD, et al. Failure of prophylactic barbiturate coma in the treatment of severe head injury. J Neurosurg 1985;62(3):383-388

98 Bradfield RB. A technique for determination of usual daily energy expenditure in the field. Am J Clin Nutr 1971;24(9): 1148-1154

99 Eisenberg HM, Frankowski RF, Contant CF, Marshall LF, Walker MD. High-dose barbiturate control of elevated intracranial pressure in patients with severe head injury. J Neurosurg 1988;69(1):15-23

100 Sakabe T, Nakakimura K. Effects of anesthetic agents and other drugs on cerebral blood flow, metabolism, and intracranial pressure. In: Cottrell JE, Smith DS, editors. Anesthesia and Neurosurgery. New York: Mosby; 2001. p. 129

101 Albanèse J, Durbec O, Viviand X, Potie F, Alliez B, Martin C. Sufentanil increases intracranial pressure in patients with head trauma. Anesthesiology 1993;79(3):493-497

102 Baguley IJ, Nicholls JL, Felmingham KL, Crooks J, Gurka JA, Wade LD. Dysautonomia after traumatic brain injury: a forgotten syndrome? J Neurol Neurosurg Psychiatry 1999; 67(1):39-43

103 Leone M, Albanèse J, Viviand X, et al. The effects of remifentanil on endotracheal suctioning-induced increases in intracranial pressure in head-injured patients. Anesth Analg 2004;99(4): 1193-1198

104 de Nadal M, Munar F, Poca MA, Sahuquillo J, Garnacho A, Rosselló J. Cerebral hemodynamic effects of morphine and fentanyl in patients with severe head injury: absence of correlation to cerebral autoregulation. Anesthesiology 2000;92(1):11-19

105 Delvaux B, Ryckwaert Y, Van Boven M, De Kock M, Capdevila X. Remifentanil in the intensive care unit: tolerance and acute withdrawal syndrome after prolonged sedation. Anesthesiology 2005;102(6):1281-1282

106 Payne PR, Wheeler EF, Salvosa CB. Prediction of daily energy expenditure from average pulse rate. Am J Clin Nutr 1971;24(9): 1164-1170

107 Papazian L, Albanèse J, Thirion X, Perrin G, Durbec O, Martin C. Effect of bolus doses of midazolam on intracranial pressure and cerebral perfusion pressure in patients with severe head injury. Br J Anaesth 1993;71(2):267-271

108 Albanèse J, Arnaud S, Rey M, Thomachot L, Alliez B, Martin C. Ketamine decreases intracranial pressure and electroencephalographic activity in traumatic brain injury patients during propofol sedation. Anesthesiology 1997;87(6):1328-1334

109 Livingstone MB. Heart-rate monitoring: the answer for assessing energy expenditure and physical activity in population studies? Br J Nutr 1997;78(6):869-871

110 Bourgoin A, Albanèse J, Wereszczynski N, Charbit M, Vialet R, Martin C. Safety of sedation with ketamine in severe head injury patients: comparison with sufentanil. Crit Care Med 2003;31(3): 711-717
111 Hsiang JK, Chesnut RM, Crisp CB, Klauber MR, Blunt BA, Marshall LF. Early, routine paralysis for intracranial pressure control in severe head injury: is it necessary? Crit Care Med 1994;22(9): 1471-1476

112 ter Minassian A, Beydon L, Decq P, Bonnet F. Changes in cerebral hemodynamics after a single dose of clonidine in severely headinjured patients. Anesth Analg 1997;84(1):127-132

113 Bourgoin A, Albanèse J, Léone M, Sampol-Manos E, Viviand X, Martin C. Effects of sufentanil or ketamine administered in target-controlled infusion on the cerebral hemodynamics of severely brain-injured patients. Crit Care Med 2005;33(5): 1109-1113

114 Maciver IN, Frew IJC, Matheson JG. The role of respiratory insufficiency in the mortality of severe head injuries. Lancet 1958;1(7017):390-393

115 Graham DI, Adams JH. Ischaemic brain damage in fatal head injuries. Lancet 1971;1(7693):265-266

116 Graham DI, Adams JH, Doyle D. Ischaemic brain damage in fatal non-missile head injuries. J Neurol Sci 1978;39(2-3):213-234

117 Graham DI, Ford I, Adams JH, et al. Ischaemic brain damage is still common in fatal non-missile head injury. J Neurol Neurosurg Psychiatry 1989;52(3):346-350

118 Murray JA, Demetriades D, Berne TV, et al. Prehospital intubation in patients with severe head injury. J Trauma 2000;49(6): 1065-1070

119 Eckstein M, Chan L, Schneir A, Palmer R. Effect of prehospital advanced life support on outcomes of major trauma patients. J Trauma 2000;48(4):643-648

120 Sloane C, Vilke GM, Chan TC, Hayden SR, Hoyt DB, Rosen P. Rapid sequence intubation in the field versus hospital in trauma patients. J Emerg Med 2000;19(3):259-264

121 Clifton GL, Robertson CS, Kyper K, Taylor AA, Dhekne RD, Grossman RG. Cardiovascular response to severe head injury. J Neurosurg 1983;59(3):447-454

122 Dimopoulou I, Tsagarakis S. Hypothalamic-pituitary dysfunction in critically ill patients with traumatic and nontraumatic brain injury. Intensive Care Med 2005;31(8):1020-1028

123 Mautes AE, Müller M, Cortbus F, et al; Homburg Traumatic Injury Group (HOTBIG). Alterations of norepinephrine levels in plasma and CSF of patients after traumatic brain injury in relation to disruption of the blood-brain barrier. Acta Neurochir (Wien) 2001;143(1):51-57, discussion 57-58

124 Rhoney DH, Parker D Jr. Use of sedative and analgesic agents in neurotrauma patients: effects on cerebral physiology. Neurol Res 2001;23(2-3):237-259

125 Dimopoulou I, Tsagarakis S, Theodorakopoulou M, et al. Endocrine abnormalities in critical care patients with moderate-tosevere head trauma: incidence, pattern and predisposing factors. Intensive Care Med 2004;30(6):1051-1057

126 Feibel JH, Hardy PM, Campbell RG, Goldstein MN, Joynt RJ. Prognostic value of the stress response following stroke. JAMA 1977;238(13):1374-1376

127 McGuire G, Crossley D, Richards J, Wong D. Effects of varying levels of positive end-expiratory pressure on intracranial pressure and cerebral perfusion pressure. Crit Care Med 1997;25(6): 1059-1062 